\title{
Utilidad de los epónimos en medicina
} Eponyms in medicine

Luego de leer el excelente artículo titulado "Origen de algunos epónimos empleados en pediatría derivados de la literatura" de los doctores Alejandro F. Donoso y Daniela S. Arriagada, ${ }^{1}$ quisiera exponer aquí las siguientes reflexiones sobre el tema.

En primer lugar, los epónimos, y sobre todo aquellos de origen literario, no sólo embellecen el leguaje médico, sino que además son evocadores de imágenes, de modo que poseen la capacidad de aglutinar ideas propias de los símbolos; es decir que pueden llegar a transmitir en pocas palabras aquello que al lenguaje científico le demandaría frases enteras, agilizando de esta forma el curso del pensamiento médico. ${ }^{2}$ Así por ejemplo, resulta más operativo hablar de un "edema Godet positivo", que de un "edema producido por acumulación de agua y sodio a nivel cutáneo, el cual deja impronta a la compresión digital, y que puede ser producto de un desequilibrio entre las presiones hidrostáticas y oncóticas de los compartimientos intravascular e intersticial y/o de un aumento de la permeabilidad capilar, inducido por causas locales (ej.: obstrucción venosa, etc.) o sistémicas (ej: insuficiencia cardíaca, renal o hepática)".

En segundo lugar, los epónimos pueden a veces constituir un reconocimiento a científicos o artistas que con sus descripciones han hecho un aporte significativo a la medicina. Esta actitud no solo constituye un "beau geste" para con nuestros ilustres antecesores, sino un recordatorio de que la disciplina médica no es un producto acabado ni nacido en forma espontánea, sino el resultado de un proceso del conocimiento que requirió y sigue requiriendo del aporte colectivo. ${ }^{3}$

En tercer lugar, los epónimos frecuentemente constituyen un puente conector entre la medicina y el resto de la cultura. Este puente facilita el flujo interdisciplinario de ideas del cual pueden emanar nuevas hipótesis y teorías científicas aplicables al campo médico. ${ }^{4}$
Finalmente, debe tenerse en cuenta que algunos epónimos con el paso del tiempo pueden volverse anacrónicos, al evocar figuras carentes de significación actual (ej: cuello proconsular) o remitir a conceptos ya perimidos (ej: rostro lombrosiano), pudiendo en consecuencia ser reemplazados por nuevos epónimos con capacidad evocadora actual o sencillamente dejar de ser utilizados.

Concluimos entonces que los epónimos aportan belleza y eficiencia al lenguaje médico, pueden homenajear a los forjadores del saber médico, y vincularlo al resto de la cultura. Sin embargo, los epónimos podrían llegar a necesitar aggiornarse o devenir obsoletos.

Palabras claves: epónimos, medicina, símbolo.

Dr. Carlos G. Musso

Departamento de Fisiología. Instituto Universitario del Hospital Italiano de Buenos Aires, Argentina

http:/ / dx.doi.org/10.5546/aap.2019.142

Texto completo en inglés:

http:/ / dx.doi.org/10.5546/aap.2019.eng.142

Cómo citar: Musso CG. Utilidad de los epónimos en medicina. Arch Argent Pediatr 2019;117(3):142.

\section{REFERENCIAS}

1. Donoso FA, Arriagada SD. Origen de algunos epónimos empleados en pediatría derivados de la literatura. Arch Argent Pediatr. 2019;117(3):188-94 .

2. Musso CG, Enz PA, Werbin E. El símbolo y su función terapéutica: en busca de sus fundamentos científicos. Arch Argent Pediatr. 2016; 114(5):403-4.

3. Lehrer J. Proust y la Neurociencia: una visión única de ocho artistas fundamentales de la modernidad. Barcelona: Paidos; 2010.

4. Root-Berstein R, Root-Berstein M.El secreto dela creatividad. Barcelona: Kairos; 2002. 